\title{
Repairing Cell Structure of Jejunum Tissue in RA-CFA Rat Model Improved by Caprine CSN1S2 Protein
}

\author{
Laili Nur Zaidah ${ }^{1,2}$, Aris Soewondo ${ }^{1}$, Fatchiyah Fatchiyah ${ }^{1,2^{*}}$ \\ ${ }^{1}$ Department of Biology, Faculty of Mathematics and Natural Sciences, University of Brawijaya, Malang, Indonesia \\ ${ }^{2}$ Research Center of Smart Molecule of Natural Genetics Resource, University of Brawijaya, Malang, Indonesia
}

\begin{abstract}
We aimed to analyze the effect of CSN1S2 protein in Etawah crossbred goat milk and yogurt on the histopathology of the jejunum and the amount of cell damage in Complete Freund's adjuvant (CFA)-induced rheumatoid arthritis (RA) rats. The rats were divided into six groups: the untreated control rats (C), control rats were given CSN1S2 protein from Etawah crossbred goat milk (CM) or yogurt (CY), RA rats, RA rats given CSN1S2 protein from Etawah crossbred goat milk (RAM) or yogurt (RAY). Hematoxylin-eosin staining was conducted for the histopathological analysis of jejunum. Statistical analysis was done using one-way ANOVA (a significance value of $p \leq 0.05$ ) followed by the Tukey test. Our study observed that the control, $\mathrm{CM}$, and $\mathrm{CY}$ group have a normal histological structure of jejunum. The damage to the jejunum structure was reported in the RA group. The milk CSN1S2 protein was able to improve the structure of jejunum villi and increase the normal cell number in the jejunum of the RA group, similar to control. The RAY group showed an impaired jejunum structure and a high number of necrotic cells as in the RA group.
\end{abstract}

Keywords: Cell structure, CSN1S2, goat milk, jejunum, rheumatoid arthritis.

\section{INTRODUCTION}

The prevalence of Rheumatoid Arthritis (RA) sufferers in Indonesia in 2013 reached 45.59\%. This value raised from the previous year, which was $29.35 \%$ in 2011 and $39.47 \%$ in 2012 [1]. The RA cases that continue to increase are related to aging, lifestyle changes, and nutritional deficiencies [2,3]. Previous research stated that RA is also associated with the inflammation of the intestine $[4,5]$. Inflammatory conditions are caused by an increase in autoreactive $T$ cells to produce proinflammatory cytokines such as interleukin-1 (IL-1), interleukin-6 (IL-6), and TNF$\alpha[6,7]$. The autoreactivity of T cells is caused by an imbalance of normal intestinal microflora. This condition can be caused by the presence of adjuvant induction [5].

Previous studies reported that RA disease induced by Complete Freund's Adjuvant (CFA) caused damage to the villi structure of ileum [8]. The jejunum is located adjacent to the ileum. The mucosal epithelial cells and jejunal villi are susceptible to damage due to the food contaminants, the cell physiological conditions (fasting, mutagens, chemical drugs, and ionizing radiation), and the inflammation of the large intestine $[9,10]$. The villus in jejunum is predicted to be impaired due to the inflammation in RA. However, the correlation between RA and

\footnotetext{
*Corresponding Address:

Prof. Fatchiyah, PhD.

Email : fatchiya@ub.ac.id

Address : Dept. Biology, University of Brawijaya, Veteran Malang, 65145
}

inflammation in jejunum has not been studied thoroughly.

The RA treatment so far is carried out by using synthetic drugs that are not only expensive but also have long-term side effects [10]. The alternative management of RA is by consuming adequate and balanced nutrition. Nutrition can be derived from vegetable or animal protein [11]. One of an animal protein source is milk. Cow milk and goat milk are rich in bioactive peptide contents from proteins such as $\alpha$-casein-S1, $\alpha$ casein-S2 (CSN1S2), $\beta$-casein, and $\mathrm{K}$-casein $[12,13]$. Previous research found a specific protein at $36 \mathrm{kDa}$ molecular weight in Etawah crossbred goat milk and yogurt that identified as CSN1S2 protein [14]. Further research is needed to investigate whether the CSN1S2 protein of Etawah crossbred goat milk and yogurt improves the jejunum of CFA-induced RA rats.

\section{METHOD \\ Experimental Animals}

This study used 24 male Wistar rats (Rattus norvegicus) with 12 weeks of age and 150-200 g of body weight. The rats were obtained from the Integrated Research and Testing Laboratory (LPPT), Gadjah Mada University, Yogyakarta, Indonesia. For one week, the acclimatization of the animals was done in the Animal Laboratory, Biosciences Institute, Brawijaya University, Malang, Indonesia. They were exposed to a 12hour light/dark cycle at room temperature with $50 \pm 5 \%$ relative humidity. They fed with a standard rat laboratory diet and drinking water. The rats were divided into six treatment groups ( $n=4$ for each group), namely the untreated 
control rats (C), control rats given CSN1S2 protein from Etawah crossbred goat milk (CM), control rats fed CSN1S2 protein from Etawah crossbred goat yogurt (CY), Rheumatoid Arthritis rats (RA), RA rats given CSN1S2 protein from Etawah crossbred goat milk (RAM), and RA rats fed CSN1S2 protein from Etawah crossbred goat yogurt (RAY).

\section{The Establishment of CFA-induced Rheumatoid} Arthritis Animal Model

Multiple doses of CFA injection established the RA rat model. The rats were injected by 100 $\mu \mathrm{L}$ of CFA (Sigma-Aldrich Inc., Saint Louis, Missouri, USA) subcutaneously using a $1 \mathrm{~mL}$ syringe. After 14 days, the $50 \mu \mathrm{L}$ of CFA was injected into the rats' intradermal. The CSN1S2 protein of Etawah crossbred goat milk and yogurt was administered to the rats 24 hours after the last CFA injection [8].

\section{Isolation of Caprine CSN1S2 Protein}

The Etawah crossbred goat milkwas obtained from the Singosari Regional Technical Implementation Unit (UPT) of Livestock in Malang, East Java, Indonesia. The milk was fermented into yogurt according to the previous research [14] with some modifications. The CSN1S2 protein from yogurt and milk was isolated according to the previous study [15]. We measured the protein concentration using the NanoDrop spectrophotometer and stored the protein at $-20^{\circ} \mathrm{C}$. The treatment of CSN1S2 protein of milk and yogurt into the rats was carried out orally for three months. The dose of CSN1S2 protein used in this study was $2 \mathrm{mg}^{\mathrm{kg}} \mathrm{kg}^{-1}$ of body weight. This research has been approved by the Research Ethics Committeeof Brawijaya University, Malang, and East Java, Indonesia (Certificate number, KEP-90-UB).

\section{Histopathological Analysis}

All rats were sacrificedto collect the jejunum. The jejunum of each rat was washed in phosphate-buffered saline (PBS) $\mathrm{pH}$ 7.4. We did the fixation of jejunum in $4 \%$ paraformaldehyde. The organs were dehydrated using graded alcohol concentration (30\%, 40\%, 50\%, 60\%, $70 \%, 80 \%, 90 \%, 96 \%)$ followed by clearing using xylene. We infiltrated our specimens with liquid paraffin at $62^{\circ} \mathrm{C}$ for 4 hours. The specimens were embedded with liquid paraffin and cooled overnight. A rotary microtome performed the serial sectioning of jejunum with $5 \mu \mathrm{m}$ of thickness. The histological slides were placed on a hot plate with atemperature of $42^{\circ} \mathrm{C}$ at least for 24 hours. Deparaffinization of tissue slides was done using xylene, followed by dehydration using a graded series of alcohol (absolute ethanol, $90 \%, 80 \%, 70 \%)$. The slides were washed using running water for 15 minutes. After that, the slides were stained with hematoxylin-eosin (HE). After staining with eosin, we washed the slides using running water and dehydrated them with $70 \%$ ethanol and $90 \%$ for 2 minutes, respectively, then continued with absolute ethanol. The sections were embedded in Entellan (Merck, Darmstadt, Germany) and covered with a cover glass. The morphology of normal cells, pyknosis, karyorrhexis, and karyolysis cells were observed using an Olympus BX 53 microscope with cellSens Standard software version 1.5 (Olympus Corporation, Tokyo, Japan) [15].

\section{Data Analysis}

Data analysis was performed by comparing the number of normal cells and necrotic cells statistically by using SPSS software version 16.0 for windows (SPSS Inc., Chicago). The results were expressed by means \pm standard deviation. We performed the statistical analysis using oneway ANOVA test followed by the Tukey test. The significance level used in this study was $\mathrm{P}<0.05$.

\section{RESULTS}

The histopathology of rat jejunum for each treatment group is shown in Figure 1 . The mucosal layer in the jejunum of control rats has a normalvillous shape. Villi are composed of columnar epithelial cells and lined with a striated border from enterocyte. In the RA group, we observed an epithelial cell exfoliation in the mucosal layer (desquamation). In addition, the infiltration of inflammatory cells to the lamina propria of villi, the reduction in the depth of the crypts, and a decrease in the distance between the muscularis mucosae to the muscularis externa have occurred in them.

The treatment of CSN1S2 protein from Etawah crossbred goat milk or yogurt into the control rats resulted in a similar jejunum tissue structure as in the control group. Interestingly, the RA rats that were given the goat milk CSN1S2 protein showed an improvement in the villous epithelial structure and an increase in the depth of the crypts. On the contrary, the mucosal layer of yogurt CSN1S2 protein-treated RA rats underwent an exfoliation, and a decrease in the crypts depth. There was also a decrease distance between muscularis mucosae and muscularis externa in the RAY group as RA group. Moreover, their villi were blunt, and adhesion occurred in them. 


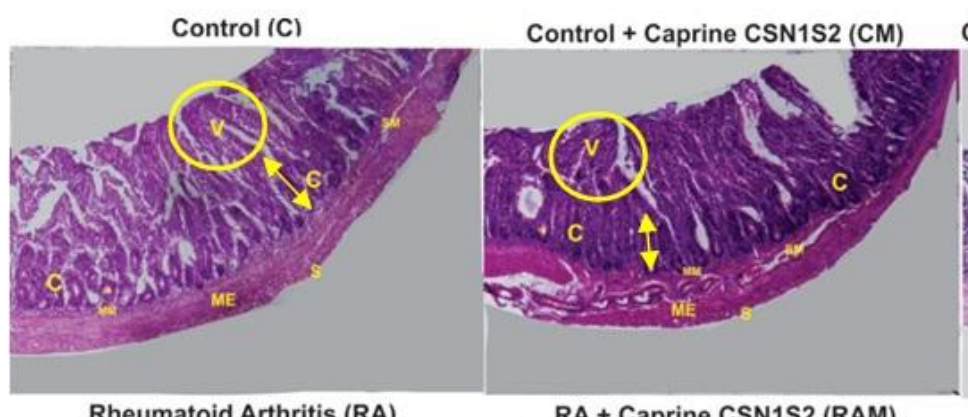

Control + Yoghurt Caprine CSN1S2 (CY)
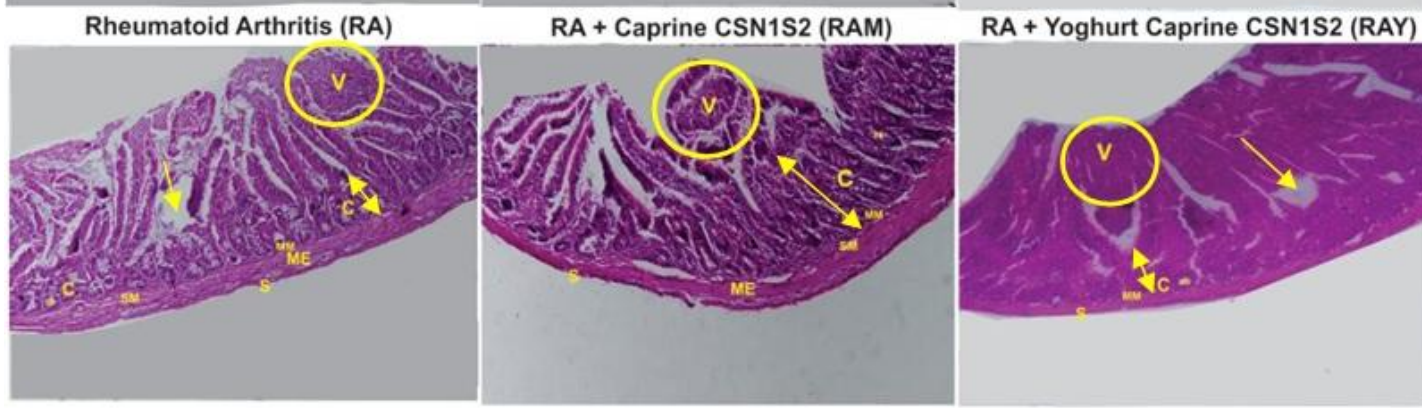

Figure1. Histopathological profile of jejunal tissues in the control and RA-CFA rat model using H\&E staining (100X magnification). Description: C- crypts; ME-muscularis externa; MM-muscularis mucosae; SB-striated border of enterocyte; S-serosa; SM-submucosa; V-villi; $\leftrightarrow$-depth of crypts; $\rightarrow$ - exfoliation of epithelial cells (desquamation); O-change in villi shape.

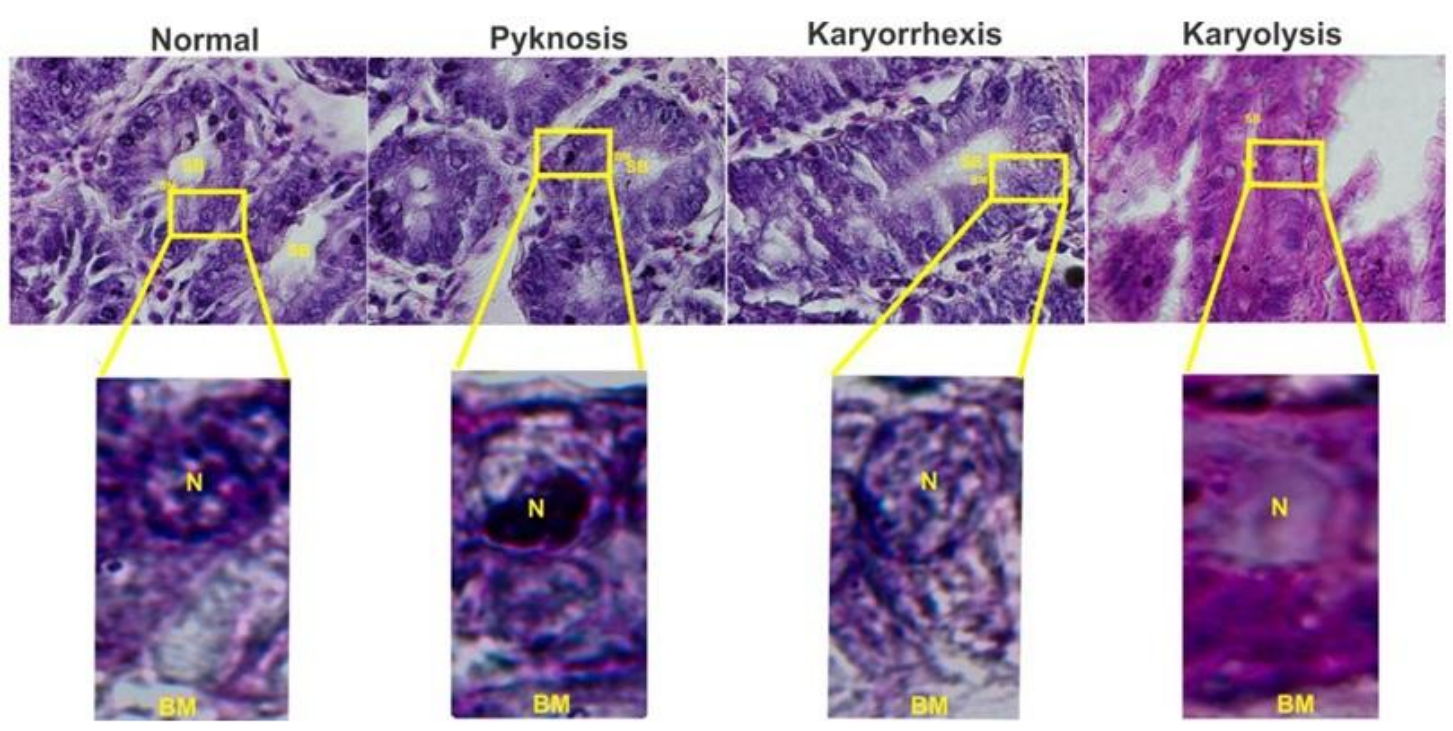

Figure 2. The histology of rat jejunal tissue shows the normal cells and necrotic cells (pyknosis, karyorrhexis, karyolysis) using H\&E staining (1000X magnification). Description: BM-basement membrane; N-Nuclear; SB-striated border of enterocyte.

Table1. The number of normal and necrotic cells in the control and RA-CFA rats model with and without treatment of Caprine CSN1S2 protein from fresh milk and yogurt.

\begin{tabular}{lllllll}
\hline \multicolumn{1}{c}{ Parameter } & \multicolumn{1}{c}{ C } & \multicolumn{1}{c}{ CM } & \multicolumn{1}{c}{ CY } & \multicolumn{1}{c}{ RA } & \multicolumn{1}{c}{ RAM } & \multicolumn{1}{c}{ RAY } \\
\hline Normal & $33.02 \pm 7.22^{\mathrm{c}}$ & $32.78 \pm 9.07^{\mathrm{c}}$ & $27.55 \pm 7.15^{\mathrm{bc}}$ & $9.93 \pm 0.70^{\mathrm{a}}$ & $29.33 \pm 2.01^{\mathrm{bc}}$ & $13.73 \pm 2.32^{\mathrm{ab}}$ \\
Pyknosis & $2.83 \pm 0.49^{\mathrm{a}}$ & $5.53 \pm 0.83^{\mathrm{ab}}$ & $6.87 \pm 0.99^{\mathrm{b}}$ & $11.53 \pm 0.99^{\mathrm{c}}$ & $4.33 \pm 1.45^{\mathrm{ab}}$ & $6.02 \pm 1.73^{\mathrm{b}}$ \\
Karyorrhexis & $2.22 \pm 1.02^{\mathrm{a}}$ & $1.00 \pm 1.73^{\mathrm{a}}$ & $2.50 \pm 2.18^{\mathrm{a}}$ & $3.11 \pm 0.19^{\mathrm{a}}$ & $1.50 \pm 1.50^{\mathrm{a}}$ & $4.31 \pm 1.68^{\mathrm{a}}$ \\
Karyolysis & $3.00 \pm 1.11^{\mathrm{a}}$ & $6.47 \pm 2.00^{\mathrm{a}}$ & $4.53 \pm 0.42^{\mathrm{a}}$ & $18.27 \pm 2.66^{\mathrm{b}}$ & $4.96 \pm 1.18^{\mathrm{a}}$ & $15.47 \pm 2.32^{\mathrm{b}}$ \\
Necrosis & $8.06 \pm 1.45^{\mathrm{a}}$ & $13.00 \pm 2.40^{\mathrm{a}}$ & $13.90 \pm 2.50^{\mathrm{a}}$ & $32.91 \pm 3.74^{\mathrm{b}}$ & $10.79 \pm 1.69^{\mathrm{a}}$ & $25.79 \pm 4.77^{\mathrm{b}}$ \\
\hline
\end{tabular}

Notes: Values are presented as mean \pm standard deviation. C: control rats group, CM: control rats group + CSN1S2 protein from Etawah crossbred goat milk, CY: control rats group + CSN1S2 protein from Etawah crossbred goat yogurt, RA: Rheumatoid Arthritis rats group, RAM: RA rats group + CSN1S2 protein from Etawah crossbred goat milk, RAY: RA rats group + CSN1S2 protein from Etawah crossbred goat yogurt. 
The cell damage can be evaluated by comparing the numberof normal cells versus necrotic cells (Fig. 2). Statistical analysis showed that the average number of normal cells in the milk CSN1S2 protein-treated control rats (32.78 \pm 9.07) and in the yogurt CSN1S2 protein-treated control rats $(27.55 \pm 7.15)$ were not significantly different from the control group (33.02 \pm 7.22$)$ (Table 1). The RA group $(9.93 \pm 0.70)$ experienced a decrease in the normal cell number compared with the control group. Compared with the RA group, the administration of CSN1S2 protein from milk or yogurt gave rise to the RA rats' normal cell number.

Our study reported that the average number of pyknosis cells in the RA group was the highestand significantly different from other groups. The CSN1S2 protein from milk or yogurt treatment reduced the pyknosis cell number in RA rats. However, the treatmentgave rise to the elevated pyknosis cell number in control rats.

The average number of cells undergoing karyorrhexis between all treatments did not differ significantly. RA rats had the highest number of karyolysis cells. The CSN1S2 protein of milk was capable of lowering the karyolysis cell number in RA rats. The control group, CM group, and $C Y$ group hadlower necrotic cell damage than the RA and RAY group. The administration of CSN1S2 protein of Etawah crossbred goat milk into the RA rats affected the necrotic cells number to decrease $(10.79 \pm 1.69)$ compared with the RA group.

\section{DISCUSSION}

The presence of CFA causes damage to the epithelial structure. CFA is composed of attenuated pathogenic bacteria, such as Enterobacter (Mycobacterium butyricum). Furthermore, pathogenic bacteria will release endotoxin compounds such as Lipopolysaccharide (LPS) [16]. CFA can cause dysbiosis, which is an imbalance between nonpathogenic and pathogenic bacteria, resulting in the dominance of pathogenic bacteria. Pathogenic bacteria can increase intestinal permeability [5]. Permeability may increase due to the decline of Tight junctions (TJs) that maintain the epithelium structure and shape. Epithelial cells in the intestinal mucosa play a role in improving barrier function. Changes in the epithelial cells of villi may interfere with lipid absorption in lymphatic or lacteal capillaries [17]. The blunt villi occurred in the RAY group was due to the accumulation of toxins in enterocytes from pathogenic bacteria, which resulted in the loss of electrolyte fluid and mucous secretion. Therefore, the villi became shorter, and cellular desquamation occurred that caused the absorption of nutrients disturbed [18].

RA and RAY groups had a decrease distance between the muscularis mucosae and the muscularis externa and a reduction in the depth of the crypts. The muscularis mucosa functions in the absorption and secretion of nutrients and villous movements. The decrease of the distance between the muscularis mucosa and can reduce villous movement so that the absorption of nutrients is impaired [19]. A reduction in the depth of the crypts can lower the anti-microbial mucus and lysozyme secretions. As a result, an invasion of bacterial pathogens may take place inducing the paneth cells to secrete tumor necrosis factor-alpha as an inflammatory mediator [17].

The CSN1S2 protein of Etawah crossbred goat milk can reduce the damage to the jejunum tissues of the RA group due to its properties as an anti-oxidative [20], immunomodulatory [21], anti-microbial [22] and anti-inflammatory compounds in tissues [8]. Besides, CSN1S2 protein can also improve the perforation in the ileum due to the accumulation of toxins in the intestine [23]. However, theCSN1S2 protein of Etawah crossbred goat yogurt was not effective in repairing the jejunum. Thatis consistent with the previous research stating that CSN1S2 protein from Etawah goat yogurt can not control normal flora in the intestine. It causes blunt villi in the ileum as well [8].

Rheumatoid arthritis is a gastrointestinal disease caused by an imbalance of intestinal microbiota. This condition is related to the ability of adjuvants to change $T$ cell responses and stimulate systemic inflammation. Adjuvants can increase intestinal permeability and facilitate antigen invasion in the lumen through the immune system in the intestinal mucosa [5]. The pathogenesis of RA disease is characterizedas an increase in cell damage and inflammatory conditions in the ileum due to the imbalance of intestinal homeostasis [8]. Pathological conditions are caused by the paneth cells secreting tumor necrosis factor-alpha as an inflammatory mediator [17]. Inflammation can cause necrosis [24]. This study revealed that the necrotic cell number in the RA group was the highest and significantly different from the other groups. The yogurt given to the control group is 
safe to consume since its number of normal and necrotic cells did not differ significantly from the control and CM group. Our study reported that CSN1S2 protein from Etawah crossbred goat milk could trigger the normal cell proliferation indicated by the high number of the cells. But, if the goat milk is fermented into yogurt, it cannot increase the normal cell number.

The SEM analysis of bone in the previous study [25] showed that the CSN1S2 protein from Etawah crossbred goat yogurt could increase phosphorus minerals but low in calcium and nickel. The increase in phosphorus enhances ATP degradation, which results in elevated inorganic phosphate in cells so that the tissue experiences hypoxia. The other study reported that Caprine CSN1S2 protein milk could improve the proliferation of normal cells and reduce the necrotic cell number in the RA group due to the physiological role of CSN1S2 protein as an antioxidative [20] and immunomodulators [21,26]. Moreover, bioactive peptides of CSN1S2 protein of Etawah crossbred goat milk can increase the proliferation of pre-osteoblast cells to control cell inflammation due to oxidative stress [25]. The yogurt from Etawah goat milk is not suitable for routine consumption by RA patients because it can result in decreased normal cells number and elevated necrotic cells. Thought, we take the recommendation that the fresh milk Etawah crossbred goat to be consumed by patients with RA as proper. However, the Etawah crossbred goat yogurt is not recommended for routine consumption due to the effect may worsen rheumatoid arthritis patients.

\section{CONCLUSION}

This study concluded that the damaged cells of jejunum villi are successfully repaired by CSN1S2 protein in fresh milk Etawah crossbred goat milk. However, the yogurt CSN1S2 protein failed the cell improvements.

\section{Acknowledgments}

This study was supported by the Professor research Grant 2019 (DIPA-042.01.2.400919/ 2019), Brawijaya University. We thank Biosains Institute, Brawijaya University, for providing the laboratory facilities. We gratefully acknowledge Pupimadita Tizar Afdora, M.Si for laboratory assistance, and Hazna Noor Meidinna, S.Si, for English proofreading.

\section{REFERENCES}

[1] Fundamental Health Research (Riset Kesehatan Dasar Riskesdas). 2013. Ofice of
Health Research and Development (Badan Penelitian dan Pengembangan Kesehatan). Indonesian Ministry of Health. Available at: http://www.depkes.go.id/resources/downl oad/general/hasilRiskesdas2013.pdf.

[2] Shlotzhauer, T.L. 2014. Living with rheumatoid arthritis. Johns Hopkins University Press. Maryland.

[3] Silva, G.B., B.Z. Reis, S.M.F. Cozzolino. 2016. Micronutrients Deficiencies in Rheumatoid Arthritis Patients. Int. J. Pathol. Clin. Res. 2(29). 1-5.

[4] Actis, G.C. 2014. The gut microbiome. Inflamm. Allergy Drug. Targets. 13(4). 21723.

[5] Yeoh, N., J.P. Burton, P. Suppiah, G. Reid, S. Stebbings. 2013. The Role of the Microbiome in Rheumatic Diseases. Curr. Rheumatol. Rep. 15(314). 1-11.

[6] Jethwa, H., S. Abraham. 2017. The evidence for microbiome manipulation in inflammatory arthritis. Rheumatology. 56(9). 1452-1460.

[7] Hochberg, M.C., A.J. Silman, J.S. Smolen, M.E. Weinblatt. 2014. Rheumatology, $6^{\text {th }}$ Ed. Mosby, Elsevier Ltd. Missouri.

[8] Rohmah, R.N., E. Widjajanto, F. Fatchiyah. 2015. Protective effect of CSN1S2 protein of goat milk on ileum microstructure and inflammation in rat-CFA-induced rheumatoid arthritis. Asian Pac. J. Trop. Dis. 5(7). 564-568.

[9] Inagaki-Tachibana, E., T. Tsukahara, K. Kaji, R. Eguchi, H. Kanazawa, H. Hayashi., Y. Suzuki. 2009. Involvement of DNA fragmentation of enterocytes in mucosal injury to a mouse jejunum incubated in using chambers. Nagoya J. Med. Sci. 71(12). 11-18.

[10] Zheng, Z., Z. Zuo, P. Zhu, F. Wang, H. Yin, X. Peng, J. Fang, H. Cui, C. Gao, H. Song, P. Ouyang, Y. Zhou, S. Zhao. 2017. Research Paper A study on the expression of apoptotic molecules related to death receptor and endoplasmic reticulum pathways in the jejunum of $\mathrm{AFB}_{1}$ intoxicated chickens. Oncotarget. 8(52). 89655-89664.

[11] Vitetta, L., S. Coulson, J. Schloss, S.L. Beck, R. Allen, A. Sali. 2012. Dietary recommendations for patients with rheumatoid arthritis: a review. Nutr. Diet. Suppl. 4. 1-15.

[12] Greppi, G.F., P. Roncada, R. Fortin. 2008. Protein components of goat's milk. In: 
Pulina, G., A. Cannas (Eds). Dairy Goats Feeding and Nutrition, $2^{\text {nd }}$ Ed. Bologna, CAB International. Oxfordshire. 71-94.

[13] Cozma, A., S. Andrei, D. Miere, L. Filip, F. Loghin. 2011. Proteins profile in milk from three species of ruminants. Not. Sci. Biol. 3(1). 26-29.

[14] Budiarti, I.K., M. Padaga, F. Fatchiyah. 2013. Nutritional composition and protein profile of goat yogurt PE with double culture between Streptococcus thermophilus and Lactobacillus Species. Cukurova Medical Journal. 38(4). 681-686.

[15] Bia, R.R., R.P. Virgirinia, B. Setiawan, A. Soewondo, F. Fatchiyah. 2015. Goat milk CSN1S2 is able to decrease the severity scoring, TNF-a, and RAGE expression in complete Freund's adjuvant-induced rheumatoid arthritis model of rats. BGM. 7. 64-71.

[16] Nagai, N., T. Tanino, Y. Ito. 2015. Excessive interleukin 18 relate the aggravation of indomethacin-induced intestinal ulcerogenic lesions in Adjuvant-Induced Arthritis Rat. Biol. Pharm. Bull. 38(10). 1580-1590.

[17] Tlaskalová-Hogenová, H., R. Stěpánková, H. Kozáková, T. Hudcovic, L. Vannucci, L. Tučková, P. Rossmann, T. Hrnčír, M. Kverka, Z. Zákostelská, K. Klimešová, J. Přibylová, J. Bártová, D. Sanchez, P. Fundová, D. Borovská, D. Srůtková, Z. Zídek, M. Schwarzer, P. Drastich, D.P. Funda. 2011. The role of gut microbiota (commensal bacteria) and the mucosal barrier in the pathogenesis of inflammatory and autoimmune diseases and cancer: contribution of germ-free and gnotobiotic animal models of human diseases. Cell. Mol. Immunol. 8(2). 110-120.

[18] Freedman, J.C., M.A. Navarro, E. Morrell, J. Beingesser, A. Shrestha, B.A. McClane, F.A. Uzal. 2018. Evidence that Clostridium perfringens Enterotoxin-induced Intestinal Damage and Enterotoxemic Death in Mice Can Occur Independently of Intestinal Caspase-3 Activation. Infect. Immun. 86(7). e00931-17.

[19] Peckham, M. 2011. Histology at a glance. John Wiley and Sons Ltd. Chichester.

[20] Chotimah, C., G. Ciptadi, B. Setiawan, F. Fatchiyah. 2015. CSN1S2 protein of goat milk inhibits the decrease of viability and increases the proliferation of MC3T3E1 preosteoblast cell in methylglyoxal exposure.
Asian Pac. J. Trop. Dis. 5(3). 219-223.

[21] Sharma, S., R. Singh, S. Rana. 2011. Bioactive peptides: a review. Int. J. Bioautomation. 15(4). 223-250.

[22] Sujono, Y. Bekti, A. Hikmawan, A. Saga, Yuananda. 2016. Use of milk goat yoghurt lowering uric acid, cholesterol and blood glucose. The $2^{\text {nd }}$ International Conference on Science, Technology, and Humanity. ISSN: 2477-3328.

[23]. Agustina, V., B. Setiawan, F. Fatchiyah. 2015. Acute toxicity of caprine alpha S2casein protein on the microstructures and mineral profiles of rat ileum. Asian Pac. J. Trop. Dis. 5(9). 721-725.

[24] Elmore, S.A., D. Dixon., J.R. Hailey, T. Harada, R.A. Herbert, R.R. Maronpot, T. Nolte, J.E. Rehg, S. Rittinghausen, T.J. Rosol, H. Satoh., J.D. Vidal., C.L. Willard-Mack., D.M. Creasy. 2016. Recommendations from the INHAND Apoptosis/Necrosis Working Group. Toxicol. Pathol. 44(2). 173-188.

[25] Fatchiyah, F., B. Setiawan, S. Suharjono, Z. Noor. 2015. The anti-osteoporosis effects of CSN1S2 protein of goat milk and yoghurt on a complete Freund's adjuvant-induced Rheumatoid Arthritis model in rats. BGM. 7. 139-146.

[26] Fatchiyah, F., S.J. Raharjo, F.R.P Dewi. 2015. Virtual Selectivity Peptides of CSN1S2 Protein of Local Goat Etawah Breeds Milk Modulate Biological Mechanism of Calmodulin. Int. J. Pharm. Bio. Sci. 6(2). 707 -718 . 